\title{
Enhancing quality of information through risk reporting in financial statements
}

\author{
Mirela NICHITA \\ The Bucharest University of Economic Studies, Bucharest, Romania \\ mirela.nichita@cig.ase.ro
}

\begin{abstract}
When we bring in discussion risk, we think about danger, loss or other unfavorable consequences. In accounting and in finance area, the concept of risk is related to a wide range of terms, such as: cost - volume analysis, decision trees, discounted cash flows, capital assets pricing models, and the newly hedging concept. Effective risk management relates to risk assessment; risk evaluation; risk treatment; and risk reporting. Risk management highlights the actions that the entity takes in order to be prepared for any negative event. The objective of risk management is not to prevent or eliminate taking risk, but is to ensure that the risks is taken with complete knowledge and clear understanding so that it can be measured to help in mitigation. The paper will emphasizes a short evolution about accounting qualitative characteristics and how these features may conduct to a more transparent reporting and a balanced risk management processes. A key principle of comprehensive risk management is risk transparency, both in terms of internal risk reporting as well as external disclosure for users of information in making decision process.
\end{abstract}

Keywords: reporting, risk, quality, financial reports, decision.

\section{Introduction}

In the recent years, many researches investigate the risk, risk reporting and how risk is managed by entities.

There is an increasing attention among users, preparers and financial analyst that risk reporting needs to improve; better risk reporting is integral to better governance. The question of how best to balance what investors and other users want to see in a risk report with what organizations are willing to disclose remains to be answered. So far, entities are hesitant to disclose anything that might threaten competitive advantage or to discuss potential risks in detail in case this distresses stakeholders. Shareholders and stakeholders are entitled to better information. "The big challenge now is the mass of companies whose risk reporting is inadequate at best. There are some shining examples, good reports that tell the story honestly and in the voice of the company. The trick now is to get the others up to speed" (ACCA, 2012).

In recent years, the nature of business has changed fundamentally. Competitive advantage increasingly involves value creation processes that rely on intangible assets not recognized in the financial statements. To serve the information needs of the market and provide the information required for corporate transparency and accountability, there is now a consensus that the business reporting model needs to expand beyond the traditional financial reporting model that emphasizes backward looking, quantified, financial information. Worldwide, narrative communication in annual reports is viewed as the crucial element in achieving the desired step-change in the quality of corporate reporting 
and regulators are focusing attention on the management discussion and analysis statement in the annual report (referred to as the MD\&A in most countries).

In the recent years, many accounting researchers concentrated their efforts on exploring the relationship between risk and capital markets and the necessity of improving the quality of financial reporting (Healy \& Palepu, 2001; Core, 2001).

\section{Literature review}

\section{Financial reporting}

The conceptual framework issued by IASB (2010), but in continuously changes is the landmark is assessing usefulness of financial reporting through qualitative characteristics of information included in financial reports; the objective of reporting is to provide to investors, lenders and other categories of users figures and narratives about resources and claims and to help them in decision - making process. Information is useful when meets the primary qualitative characteristics (relevance and faithful representation) and enhancing characteristics (comparability, timeless, verifiability and understandability. Relevant information has confirmatory or predictive value. Faithful representation means that the information reflects the real-world economic phenomena that it purports to represent.

The quality of financial information users receive is a function of both the quality of (accounting) standards governing the disclosure of accounting information and the regulatory enforcement or corporate application of the standards in an economy.

The benefits obtained from worthy financial disclosure explain the demand for high quality accounting standards and disclosure structures. The theoretical literature shows that both mandated and voluntary disclosures reduce information asymmetries among informed and uninformed market participants (Diamond \& Verrecchia, 1991). Kothari (2015) underlines that reduced information asymmetry lowers the cost of capital by shrinking bid-ask spreads, enhancing trading volume, and reducing stock-return volatility (Leuz \& Verrecchia, 2000). The agent theory states that always will be an information asymmetry between stakeholders, especially between shareholders and managers (Jensen \& Meckling, 1976). The role of international accounting standards it is to deliver supervision in preparing financial statements to reduce the biases between users. Thus, the better the financial reports are, the more efficient is the control the principal has on the agent. IFRS adoption is encouraged because it may improve the quality and international comparability of financial reporting (Brown \& Tarca, 2005).

Through transparency, information users must be able to determine the nature and accounting treatment of company operations. Full disclosure occurs when financial reports facilitate the understanding of accounting practices and decision-making. From this point of view, IFRS are regarded as quality standards that enable comparability and foster transparency and full disclosure. Although IFRS are considered to be high-quality standards, there is a concern whether they will be appropriately implemented. An important issue that could influence IFRS implementation is acceptability. The greater the acceptance, the greater the compliance with standards. Pownall and Schipper (1999) provide empirical evidence on cross-country differences in the strictness of accounting standards' application and interpretation. Wulandari and Rahman (2004) indicate that accounting standards should be of good quality, acceptable and enforceable in order to improve financial reporting. 
To assess the quality of financial reporting, various measurement methods have been used: accrual models, value relevance models, research focusing on specific elements in the annual statement, and methods operationalizing the qualitative characteristics (van Beest et al., 2009). Financial reporting quality is a comprehensive theory that not only raises from financial information, but also from disclosures, and other non-financial information useful for decision making included in the report (Kythreotis, 2014).

\section{Risk and financial reporting}

The entities' financial reports are fragile in risk reporting, due to the fact that information about risk is more qualitative and the preparers may feel uncomfortable to disclose it in narratives, being a symbolic reporting (Abraham \& Shrives, 2014). The researchers confirm the lack of risk disclosures in financial reports (Beretta \& Bozzolan, 2004; Mohobbot, 2005). Investors appreciate any complementary information, considering it an advantage in making decision process.

In risk reporting analysis, disclosure index is highly used and is based on text analysis piloted through a list of items. There is a lack of papers exploring the financial reporting area of entities from transition economy. Pervan et al. (2010) made a comparative analysis of the financial reporting practice of listed companies in six Eastern European countries. They found significant differences in the regulation and practice of mandatory financial reporting.

The research conducted by Hodder at al. (2006) pointed out that income based on fair value is risk-relevant and all the gains and losses generated by fair value base is incrementally risk relevant. The researchers recommend to preparers of financial reports to take full advantage of connections between financial statements and to inform users about variances between economic and estimation risks that entities face during their existence (Hodder at el., 2006). This approach in reporting will ensure comparability among reporting entities and to facilitate interpretation of financial numbers and decision making process (Yates et al., 1997; Koonce et al., 2011).

Robb at al. (2001) analyzed non-financial data from financial reports of entities across Australia, Canada and USA and grouped the data into two main categories: forward looking (environmental outside entity, strategic and trend information) and backward looking (internal environment, production and customers) each of them with three subcategories, as mentioned above. The differences in disclosure are due to the size on entity, industry, country. The same methodology was applied by Vanstraelen et al. (2003) when analyzed financial reports of companies from Belgium, Germany and Netherlands.

The Flesch index, which measures the readability of financial reports, used by Jones and Shoemaker (1994) revealed a high value leading to the conclusion that financial reports are difficult to understand, despite the recommendation of Conceptual Framework to safeguard understandability, as an enhancing qualitative characteristic.

Quantitative methods in assessing the effectiveness of risk are used by Bodea \& Purnus (2012) in project management and conclude that accuracy of Monte Carlo method is shadowed by difficulty in understanding and interpreting its results for many managers. 


\section{Methodology}

Mainly, in accounting research papers, there are two approaches: deductive and inductive. Deductive methodology starts with developing the hypothesis followed by testing them; by contrary, the inductive methodology, the data are collected and the theory is settled based on the results of data analysis (Saunders et al., 2009).

This paper makes use of deductive approach and the financial reports of ten the most valuable Romanian companies were analyzed to discover how risk is reported. The data of research are secondary data and a period of 3 years is covered. The paper creates the grounds for replication for further researches.

For this paper, business risks were investigated; they may be split up into various categories; the differentiation used in this research will be the same as the one used in the Linsley and Shrives (2006) study which can also be found in the business risk model published by PricewaterhouseCoopers (2005). The categories are: financial risk, operations risk, empowerment risk, information processing technology risk, integrity risk and strategic risk.

Financial risk $^{1}$ can defined as the risk that a given firm cannot meet its financial obligations; this category can be split up into sub categories: Interest rate a financial risk is known as the movements in the interest rate that can affect the firm's borrowing costs, investment yields or asset values. The exchange rate risk is the chance that a firm is exposed to volatile exchange rates that can cause economic and accounting losses. Commodity risk is the risk that can cause losses for a firm reliant on commodities, due to fluctuation in price, which can lead to lower margins or trading margins. Liquidity risk is the risk that a firm is in able to meet its cash flow obligations in a timely manner. Credit risk, is the risk that a firm cannot acquire financing due to bad credit rating or pay off its obligations. (Pricewaterhouse Coopers, 2005)

The next main category is the operations risk $^{2}$, this can be described as the risk that the firms operations fails to meet its objectives. This category can also be split up into subcategories such as customer satisfaction, which is the risk that the lack of focus on the customers' expectations threatens the firm's capacity.

Compliance (Regulatory and other) risk can be described as the risk a company faces as the result of not complying with rules and regulations. Another risk under the same category is the product development risk, this is the risk the firm does not develop a product to meet the customers' needs/wants.

There is also the efficiency and performance risk, which is the lack of efficiency and performance that could threaten the firm's capacity to produce goods at a competing level in the market it operates. Sourcing risk can be best described the lack of resources affects the ability to produce the required goods at timely/efficient/high quality basis.

Another one is the stock obsolescence and shrinkage that is when a firm does not possess stock to sell, which in turn means the risk of not making revenue. Product and service failure risk is due to faulty product or service, firm faces the risk of extra cost and/or loss of market share.

\footnotetext{
${ }^{1}$ Financial Risk = "the risk that cash flows and financial risks are not managed cost effectively to (a) maximize cash availability, (b) reduce uncertainty of currency, interest rate, credit and other financial risks, or (c) move cash funds quickly and without loss of value to wherever they are needed the most." (PricewaterhouseCoopers 2005)

2 Operations risk = "is the risk that operations are inefficient and ineffective in executing the firm's business model, satisfying customers and achieving the firm's quality, cost and time performance objectives." (PricewaterhouseCoopers, 2005)
} 
Environmental risks are activities harmful to the environment with consequences that could harm the firm's image.

Health and safety risk are activities that put the health and safety of employees of a firm at risk.

Brand name erosion is the risk that the company's activities erode the brand name that is of importance to the company. "Business interruptions stemming from the unavailability of raw materials, information technologies, skilled labor, facilities or other resources threaten the firm's capacity to continue operations." (Pricewaterhouse Coopers, 2005).

Empowerment risk ${ }^{3}$ as the definition describes is the risk that employees are not properly led or controlled, this means is that they then act upon themselves and thus leading to the risk that the management loses control over its employees. This risk category as the previous ones can be split up into various types. The first one is called leadership risk is the risk of a lacking leader or leadership on its own, which can lead to lack of motivation, loss of direction, non-existing customer focus and the management's credibility takes a toll. Outsourcing risk is the risk a firm takes in handing over certain responsibilities to another firm that doesn't meet expectations/objectives. Performance incentives risk is when the employees or management receive the improper amount of incentives that influences the performance. Change readiness risk is when the people within a firm are unable to implement new system or product quickly enough. Communications risk the risk that messages are improperly communicated that can lead to an inconsistency with authorized responsibilities and established performance measures. (PricewaterhouseCoopers, 2005)

Information processing/technology risk ${ }^{4}$ is the risk that the IT does not meet expectations and/or not operating in the manner intended, which can lead to a misappropriation of assets, exposing the firm inability to sustain critical processes. Integrity risk, a sub category, is the risk of insufficient and/or improper authorization/transaction controls that can be inaccurate. Access risk is the risk of unauthorized access to data. Availability risk is the risk that the data in unavailable as the time it is needed. Infrastructure risk is when a given firm's infrastructure does not meet the requirements to harbor equipment needed to process the firm's data. (PricewaterhouseCoopers, 2005).

Integrity risk ${ }^{5}$ is the risk of fraud or any other unauthorized occurring within the firm by management and/or employees that can lead to a loss in reputation. The subcategories are the same as mentioned here; there is a risk that the management or employees can commit fraud. This could lead to the misappropriation of assets. Or an illegal act can lead to litigation or other consequences following an illegal act. Fraud or an illegal act can be harmful to a firm's image and lead to a loss in their reputation; certain firms (assurance firms) need this reputation to be able to operate in the market. (PricewaterhouseCoopers, 2005).

\footnotetext{
${ }^{3}$ Empowerment risk = "Empowerment risk is the risk that managers and employees (a) are not properly led, (b) don't know what to do when they need to do it, (c) exceed the boundaries of their assigned authorities, or (d) are given incentives to do the wrong thing." (PricewaterhouseCoopers 2005)

${ }^{4}$ Information processing technology risk = "Information processing technology risk is the risk that the information technologies used in the firm (a) are not operating as intended, (b) are compromising the integrity and reliability of data and information, (c) are exposing significant assets to potential loss or misuse, or (d) are exposing the firm's ability to sustain the operation of critical processes." (PricewaterhouseCoopers 2005)

${ }^{5}$ Integrity risk ="Integrity risk is the risk of management fraud, employee fraud, illegal acts and unauthorized acts, any or all of which could lead to reputation loss in the marketplace." (PricewaterhouseCoopers, 2005)
} 
Strategic risk can be defined as the risk when the strategy laid out does not coincide with the firm's goals and objectives. Environmental scan risk one of the categories, is the failure to monitor the external environment surrounding the firm. Industry risk is the risk the industry in which the firm is operating could be viable for long term plans. Business portfolio risk is the risk of relevant information that allows management to properly prioritize products or balance its businesses in a strategic context in order to optimize its performance. Competitor risk is the risk that the competition could impair the firm's ability to complete or even exist. Pricing risk is a common risk among businesses, this is the risk that the pricing in the market affects the firm's ability to function in a normal manner and meet it objectives. Valuation risk is when the firm's assets are not valued properly and thus leads to improper decision making. Planning risk is when the planning process threatens the information flow and the firm's capacity to formulate business strategies. Sovereign/political risk is when the political actions that could threaten a given firm's recourses and/or cash flows. Life cycle risk can be described is the risk a firm faces when there a lack of information regarding the product that impair could the management's decision making ability to properly make adjustments according to the situation. Measurement risk; lack or nonexistent performance measures that are inconsistent with the firm's strategies and could possibly impair the ability to execute the firm's strategy. "Pension fund risk; Incomplete and/or inaccurate information pertaining to compensation and benefits (pension plans, deferred compensation plans, retiree medical plans, etc.) may preclude the firm from meeting its defined obligations to employees on a timely basis and result in a loss of morale and reputation, work stoppages, litigation and additional funding requirements." "Taxation risk: Failure to accumulate and consider relevant tax information may result in non-compliance with tax regulations or adverse tax consequences that could have been avoided had transactions been structured differently." (PricewaterhouseCoopers, 2005). For each category of risk is possible to assign a degree of relevance and faithful presentation.

\section{Sample and data collection}

This paper uses a content analysis approach to discover how risk is reported by 10 most valuable Romanian companies in 2016; the classification is prepared by Ziarul Financiar and published in ePaper "Cele mai valoare companii din Romania" and online. This paper is a content research and analyzes the financial reports of sample of entities to identify the categories of risk presented and the manner of presentation. On long term, the goal of research is to elaborate a longitudinal analysis of risk reporting by Romanian entities and to propose a matric to assess the value of risk reporting in correlation with management and investor decisions (ACCA survey, 2012). Top 10 most valuable Romanian companies is a mix of domestic companies and international groups. The Romanian entities do not publish online annual financial reports, which conduct to shrink our sample and to analyses only international groups' financial reports. This paper covers the period 2013 - 2016, being an introduction for further research.

The sample of companies used in current research is presented in Table 1. 
Table 1. Companies

\begin{tabular}{|c|c|c|c|c|}
\hline \multicolumn{5}{|c|}{ Year } \\
\hline & 2016 & 2015 & 2014 & 2013 \\
\hline 1 & HIDROELECTRICA & HIDROELECTRICA & OMV & OMV \\
\hline 2 & OMV & $\mathrm{OMV}$ & ROMGAZ & ROMGAZ \\
\hline 3 & ROMGAZ & ORANGE & ORANGE & ORANGE \\
\hline 4 & AUTOMOBILE DACIA & AUTOMOBILE DACIA & HIDROELECTRICA & VODAFONE ROMANIA \\
\hline 5 & ORANGE & ROMGAZ & AUTOMOBILE DACIA & $\mathrm{N} / \mathrm{A}$ \\
\hline 6 & DEDEMAN & TELEKOM & VODAFONE ROMANIA & $\mathrm{N} / \mathrm{A}$ \\
\hline 7 & $\begin{array}{l}\text { CONTINENTAL } \\
\text { AUTOMOTIVE } \\
\text { PRODUCTS } \\
\end{array}$ & VODAFONE ROMANIA & RCS \& RDS & $\mathrm{N} / \mathrm{A}$ \\
\hline 8 & URSUS BREWERIES & $\begin{array}{l}\text { CONTINENTAL AUTOMOTIVE } \\
\text { PRODUCTS }\end{array}$ & TELEKOM & $\mathrm{N} / \mathrm{A}$ \\
\hline 9 & KAUFLAND ROMANIA & RCS \& RDS & $\begin{array}{l}\text { CONTINENTAL AUTOM } \\
\text { PRODUCTS }\end{array}$ & TIVE \\
\hline 10 & VODAFONE ROMANIA & KAUFLAND ROMANIA & KAUFLAND ROMANIA & $\mathrm{N} / \mathrm{A}$ \\
\hline
\end{tabular}

For start, for each entity, the words 'risk" and "risk management" were counted; then, an analysis about risk description was conducted.

\section{Results and discussions}

According to Beretta and Bozzolan (2004) the quality of risk disclosures does not only depend on the quantity of disclosure, but also on the content, the richness of the disclosed information. In their research quality is a function of quantity, density, depth and the outlook profile.

\section{Quantity of disclosure}

The simplest and easiest way to measure the quantity of risk reporting is to count the word "risk"; also, for purpose of research, the word "risk management" is counted too.

Table 2. Quantity disclosure of risk (1)

\begin{tabular}{clrr} 
Year & & "Risk" & "Risk management" \\
\hline \multirow{2}{*}{2016} & mean & 189,00 & 24,86 \\
& median & 172,00 & 26,93 \\
& STD & 130,06 & 17,94 \\
\hline \multirow{2}{*}{2015} & mean & 222,33 & 26,33 \\
& median & 202,50 & 25,67 \\
& STD & 169,12 & 19,86 \\
\hline \multirow{2}{*}{2014} & mean & 218,00 & 23,44 \\
& median & 198,00 & 24,72 \\
& STD & 170,44 & 17,10 \\
\hline \multirow{2}{*}{2013} & mean & 139,40 & 19,20 \\
& median & 104,00 & 20,00 \\
& STD & 76,89 & 13,92 \\
\hline
\end{tabular}

Source: Authors' own research 
In relationship with number of pages of annual report, an increase in using the terms "risk" and "risk management" is identified.

Table 3. Quantity disclosure of risk (2)

\begin{tabular}{|c|c|c|c|c|c|c|c|c|}
\hline & \multicolumn{2}{|c|}{2016} & \multicolumn{2}{|c|}{2015} & \multicolumn{2}{|c|}{2014} & \multicolumn{2}{|c|}{2013} \\
\hline & $\begin{array}{c}\text { "Risk" } \\
\text { word } \\
\text { weight } \\
\text { in total } \\
\text { no pages }\end{array}$ & $\begin{array}{c}\text { "RM" } \\
\text { weight } \\
\text { in total } \\
\text { no } \\
\text { pages }\end{array}$ & $\begin{array}{c}\text { "Risk" } \\
\text { word } \\
\text { weight } \\
\text { in total } \\
\text { no pages }\end{array}$ & $\begin{array}{c}\text { "RM" } \\
\text { weight } \\
\text { in total } \\
\text { no } \\
\text { pages }\end{array}$ & $\begin{array}{c}\text { "Risk" } \\
\text { word } \\
\text { weight in } \\
\text { total no } \\
\text { pages }\end{array}$ & $\begin{array}{c}\text { "RM" } \\
\text { weight } \\
\text { in total } \\
\text { no } \\
\text { pages }\end{array}$ & $\begin{array}{c}\text { "Risk" } \\
\text { word } \\
\text { weight } \\
\text { in total } \\
\text { no } \\
\text { pages }\end{array}$ & $\begin{array}{c}\text { "RM" } \\
\text { weight } \\
\text { in total } \\
\text { no } \\
\text { pages }\end{array}$ \\
\hline HIDROELECTRICA & $34,94 \%$ & $4,82 \%$ & $72,29 \%$ & $4,82 \%$ & $67,05 \%$ & $6,82 \%$ & N/A & $\mathrm{N} / \mathrm{A}$ \\
\hline OMV & $80,00 \%$ & $13,75 \%$ & $139,74 \%$ & $26,92 \%$ & $115,70 \%$ & $26,74 \%$ & $116,88 \%$ & $24,38 \%$ \\
\hline ROMGAZ & $42,36 \%$ & $18,72 \%$ & $72,50 \%$ & $30,00 \%$ & $66,39 \%$ & $23,77 \%$ & $55,56 \%$ & $14,81 \%$ \\
\hline AUTOMOBILE DACIA & $139,00 \%$ & $3,00 \%$ & $149,33 \%$ & $4,00 \%$ & $132,53 \%$ & $7,23 \%$ & $119,54 \%$ & $6,90 \%$ \\
\hline ORANGE & $143,52 \%$ & $14,81 \%$ & $94,90 \%$ & $10,20 \%$ & $82,83 \%$ & $6,06 \%$ & $81,63 \%$ & $6,12 \%$ \\
\hline CONTINENTAL AUTOMOTIVE PRODUCTS & $144,25 \%$ & $12,83 \%$ & $134,51 \%$ & $11,06 \%$ & $121,14 \%$ & $10,57 \%$ & N/A & $\mathrm{N} / \mathrm{A}$ \\
\hline VODAFONE ROMANIA & $176,79 \%$ & $22,77 \%$ & $166,20 \%$ & $23,15 \%$ & $163,89 \%$ & $14,81 \%$ & $130,73 \%$ & $13,02 \%$ \\
\hline TELEKOM & $\mathrm{N} / \mathrm{A}$ & $\mathrm{N} / \mathrm{A}$ & $206,03 \%$ & $19,15 \%$ & $185,35 \%$ & $15,61 \%$ & N/A & $\mathrm{N} / \mathrm{A}$ \\
\hline RCS \& RDS & $\mathrm{N} / \mathrm{A}$ & $\mathrm{N} / \mathrm{A}$ & $97,40 \%$ & $6,77 \%$ & $101,55 \%$ & $5,67 \%$ & N/A & N/A \\
\hline
\end{tabular}

\section{Quality of disclosure}

The companies' financial reports are weak in risk reporting, due to the fact that information about risk is more qualitative and the preparers may feel uncomfortable to disclose it in narratives, being a symbolic reporting (Abraham and Shrives, 2014).

Lately, entities changed their view about risks, from compliance to adding value; this switch was welcomed by users (ACCA, 2014). High-quality risk reporting increases investor confidence, not just in terms of the risks being discussed, but also in the overall quality of management", (ACCA, 2014). Comprehensive but targeted risk disclosures help investors to make comparisons between companies and between the actions and behaviors of their management, "weighing up their attitude and appetite towards particular areas of risk" (ACCA, 2014).

All entities used in research are dealing with financial risks, due to exchange rates, credit risk and / or financial instruments.

\section{Risk description in Annual reports of selected companies:}

\section{Hidroelectrica}

The hydrological situation - The level of production is limited both by the installed capacity as well as by the predominant hydrological situation. Unfavorable weather, representing little precipitation, affects production capacity and the ability to fulfill contractual obligations, while humid weather offers an opportunity to attempt increasing revenues from additional production.

\section{OMV Petrom}

Strategic risks arise, for example, from changes in technology, risks to reputation or political uncertainties. OMV operates in countries that are subject to political uncertainties, in particular Libya, Yemen, Pakistan, Tunisia and Turkey. 
Operational risks include all risks related to physical assets, HSSE, regulatory/compliance risks or project risks.

Risk identification, risk analysis, risk evaluation, risk treatment, reporting and risk review through continuous surveillance of changes to the risk profile. Overall risk resulting from the bottom-up risk management process is computed with the aid of Monte Carlo simulations and compared against planning data.

PICBE $\mid 679$

In 2014, OMV Petrom has implemented together with the Institute of Risk Management UK an internal company-wide training program called "Petrom Risk Academy" which contributed to the enhancement of the risk management competences within top and middle management, as well as within employees without managerial responsibilities.

Petrom has four levels of risk management roles in a pyramid-type risk organization

\section{Romgaz}

Mission of Romgaz: Performance, competition and continuous growth of the company's value both for us and for the shareholders by means of a better valuation of the human potential and assets, by predictable and profitable business deals and a better risk management.

Some of the analyzed risk categories are: financial risks, market risks, risks related to occupational health and safety, personnel risks, risks related to informational systems, legal and regulating risks.

Automobile Dacia (Renault)

The Group is exposed to the following financial risks: Liquidity risks; Market risks (foreign exchange, interest rate, equity and commodity risks); Counterparty risks; Credit risks.

Vodafone

We have a clear framework for identifying and managing risk, both at an operational and strategic level. Our risk identification and mitigation processes have been designed to be responsive to the ever-changing environments in which we operate.

Vodafone's annual report dedicates a chapter to risk and risk management full with graphs and charts. This company has a very responsible approach toward risk and risk management.

\section{Continental}

The order of the risk categories and individual risks presented within the four risk groups reflects the current assessment of the relative risk exposure for Continental and thus provides an indication of the current significance of these risks. As part of the implementation of our integrated GRC.

\section{Conclusions and final remarks}

There is clearly a gap between what investors want from a risk report and what companies believe is appropriate to disclose. Many companies argue that providing any more detail than they currently do would require them to disclose commercially sensitive information.

Contribution of research to accounting literature

The paper is a first step for an elaborate research about how Romanian companies are reporting risk and their vision about risk and risk management. 
Robustness of research

Our findings are consistent with researches conducted by Beretta and Bozzolan (2004), Mohobbot (2005), risk reporting being presented only in relationship with financial instruments because international accounting standards required, as a general statement (Romgaz) or is mandatory for Corporate Governance (Continental).Vodafone has a very comprehensive presentation of risk using graphs and analysis of risk with impact on business strategy; the financial reports highlight the action taken by management to cope with risks.

\section{Limitation of research}

Limited number of companies used in research represent the first limit of paper; the short period of time is the second limit. Other deficiency is the top realized by paper Ziarul financiar; their article doesn't offer many details about how the value of companies is computed and the previous tops are not available online, only in printed version of paper based on request and subscription. Some of domestic companies not being listed on stock exchange market do not publish online their annual financial reports. The biggest concern about existing reports is that they are rigid, generic and too PR-oriented.

Further work on topic of research

The research is the first attempt of a larger analysis of financial reports prepared by Romanian companies. The new project of IASB may enhance entities to a more detailed presentation of risk; financial reports are useful when they present relevant and faithful information. The recent financial distress should be a landmark for risk reporting and a start for creating a framework for presentation of business risks. Along with presentation of risk, models for assessing its value will be developed and tested. Does risk reporting is a disruptive risk of financial reporting?

\section{Final remarks}

Investors appreciate any complementary information, considering it an advantage in making decision process. The work of Linsley and Shrives $(2000,2005)$ based on financial reports issued by companies in different years, emphasizes that a major advantage of risk reporting is a reduction in cost of capital and investors appreciate the forward - looking attitude is risk reporting. A question arises: what is wrong with risk reporting today? In general, the respondents of an ACCA survey (2014) mention the generic perspective, politically correct approach and biased towards positivism and being unsuccessful in proving specific information about risk; the balance between needs and offer is delicate and increases the pressure on preparers of financial reports to include some information that management considers internal and strategic. What is the future of risk reporting? More standardization of reporting of risk around the world would in theory be a good thing. IASB starts a new project about risk Dynamic risk Management: The Board is exploring whether it can develop an accounting model that will provide users of financial statements with better information about a company's dynamic risk management activities and how it manages those activities (IFRS.org). 


\section{References}

Abraham, S. \& Shrives, P. (2014) Improving the relevance of risk factor disclosure in corporate annual reports, The British Accounting Review, 46, 91-107

ACCA, (2014). Risk reporting, Retrieve from http://www.accaglobal.com/ content/dam/ acca/global/PDF-technical/financial-reporting/pol-afb-rr.pdf

Beretta, S., \& Bozzolan, S. (2004) A framework for the analysis of firm risk communication. The International Journal of Accounting, 39(3), 265-288

Bodea, C.N. \& Purnus, A. (2012). Project risk simulation methods - a comparative analysis. Management and Marketing Challenges for the Knowledge Economy, 4, 565-580

Brown, P. \& Tarca, A. (2005). A commentary on issues relating to the enforcement of International Financial Reporting Standards in the EU. European Accounting Review, 14(1), 181-212.

Cohen, R., Polk, C., \& Vuolteenaho T. (2009). The price is (almost) right. Journal of Finance, 64(6), 2739-2782.

Core, J. (2001). A Review of the empirical disclosure literature: discussion, Journal of Accounting and Economics, 31, 441-456

Diamond, D., \& Verrecchia R. (1991). Disclosure, Liquidity, and the Cost of Capital, Journal of Finance, 46, 1325-1360.

Fama, E.F., \& French, K.R. (1992). The cross-section of Expected Stock Returns. Journal of Finance, 47, 427-486.

Healy, P. M., \& Palepu, K.G (2000). Information asymmetry, corporate disclosure and the capital markets. A Review of the Empirical Disclosure Literature. Retrieved from http:// ssrn.com/abstract $=258514$

Healy, P.M., \& Palepu, K.G. (2001). Information asymmetry corporate disclosure, and the capital markets: A review of the empirical disclosure literature, Journal of Accounting and Economics, 31, 405-440.

Hodder, L. (2002). Reliability and relevance of SEC market risk disclosures by commercial banks. Working Paper, Stanford University.

Hodder, L., Koonce, L., \& McAnally, M. L. (2001). SEC market risk disclosures: Implications for judgment and decision making. Accounting Horizons, 15(1), 49-70.

Jensen, M.C., \& Meckling W.H. (1976). Theory of the firm: Managerial behaviour, agency costs and ownership structure. Journal of Financial Economics, 3, (4), 305-360.

Jones, M. \& Shoemaker, P. (1994). Accounting narratives: a review of empirical studies of content and readability. The Journal of Accounting Literature, 13, 142-184.

Koonce, L., Nelson, K. K., \& Shakespeare, C. M. (2011). Judging the relevance of fair value for financial instruments. The Accounting Review, 86(6), 2075-2098.

Koonce, L., Williamson, M., \& Winchel. J. (2010). Consensus information and nonprofessional investors' reaction to the revelation of estimate inaccuracies. The Accounting Review, 85 (3), 979-1000.

Kothari, S.P. (2015). The role of financial reporting in reducing financial risks in the market. Retrieved from http://www.economicadventure.org/economic/conf/conf44/cf446 .pdf

Kythreotis, A. (2014). Measurement of financial reporting quality based on IFRS conceptual framework's fundamental qualitative characteristics, European Journal of Accounting, Finance \& Business, 2 (3), 4-29. 
Leuz, C. \& Verrecchia, R. (2000). The Economic Consequences of Increased Disclosure, Working Paper, University of Pennsylvania.

Linsley, P. M., \& Shrives, P. J. (2006). Risk reporting: A study of risk disclosures in the annual reports of UK companies. The British Accounting Review, 38, 387-404.

Mohobbot, A. (2005). Corporate risk reporting practices in annual reports of Japanese companies. Journal of Japanese Association for International Accounting Studies, 113-133.

Nekrasov, A. \& Shroff, P. K. (2009). Fundamentals-Based Risk Measurement in Valuation. The Accounting Review, 84(6), 1983-2011.

Pervan, I., Horak, H., \& Vasilj, M. (2010). Financial reporting regulation for the listed companies: Analysis for selected Eastern European transitional countries in the process of EU enlargement. Economic Thought and Practice, 19, 277-309.

Pivac, S., Vuko, T., \& Cular, M. (2013). Comparative analysis of annual report disclosure quality for Slovenian and Croatian listed companies. Dolenjske Toplice: Proceedings of the $12^{\text {th }}$ International Symposium on Operational Research, 305-311.

Pivac, S., Vuko, T., \& Cular, M. (2017). Analysis of annual report disclosure quality for listed companies in transition countries, Economic Research-Ekonomska Istraživanja, 30(1), 721-731.

Pownall, G. \& Schipper, K. (1999). Implications of Accounting Research for the SEC's Consideration of International Accounting Standards for U.S. Securities Offerings, Accounting Horizons, 13, 259-280.

PricewaterhouseCoopers (2005). Risk Perspectives. Bringing together leading risk management insights from the banking industry. Retrieve from https://www.pwc.com/gx/en/banking-capital-markets/pdf/riskperspectives.pdf

Robb, S. W. G., Single, L. E. \& Zarzeski, M. T. (2001). Nonfinancial Disclosures across AngloAmerican Countries. Journal of International Accounting, 10(1), 71-83.

Ryan, S.G. (1997). A survey of research relating accounting numbers to systematic equity risk: Implications for risk disclosure policy and future research. Accounting Horizons, 11(2), 82-95.

Ryan, S.G. (2011). Risk Reporting Quality: Implications of Academic Research for Financial Reporting Policy, Retrieve from SSRN: https://ssrn.com/abstract=1970088

Saunders, M., Thornhill, P., \& Lewis, A. (2009). Research Methods for Business Students, $5^{\text {th }}$ Edition, Prentice Hall.

Van Beest, F., Braam, G., \& Boelens, S. (2009). Quality of Financial Reporting: measuring qualitative characteristics. NiCE Working Paper 09-108. Institute for Management Research. Radboud University Nijmegen.

Vanstraelen, A., Zarzeski, M.T. \& Robb, S.W.G. (2003). Corporate Non-Financial Disclosure Practices and Financial Analyst Forecast Ability Across Three European Countries. Journal of International Financial Management \& Accounting, 14, 249-278.

Wulandari, R. E. \& Rahman, A.R. (2004). A Cross-country study on the Quality, Acceptability and Enforceability of Accounting standards and the Value Relevance of Accounting Earnings, http://www.oecd.org/finance/financial-markets/33735584.pdf.

Yates, F., Lee, J., \& Bush, J., (1997). General Knowledge Overconfidence: Cross-National Variations, Response Style, and "Reality". Organizational behaviour and human decision processes, 70(2), 87-94. 